\title{
間欠的漸増負荷走行中の血中乳酸動態から推定されるパワーと中距離走能力との関係
}

\author{
森丘保 典 $^{1)}$ 伊藤静 夫 $^{1)}$ 大庭恵 - ${ }^{2}$ 原 孝 子 ${ }^{1}$ )

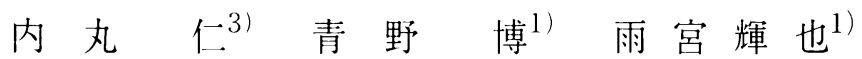

\section{RELATIONSHIP BETWEEN MIDDLE-DISTANCE RUNNING PERFORMANCE AND POWERS ESTIMATED FROM BLOOD LACTATE CONCENTRATION DURING INTERMITTENT RUNNING}

\author{
Yast jori Morioka, Shizlo Ito, Keilchi Ohba, Takako Hara, Jin Uchimarl, \\ HiROSHI AONO and TARUYA AMEMIYA
}

\begin{abstract}
This study was conducted to clarify the relationship between power estimated by blood lactate movement during intermittent running test (Maximal Anaerobic Running Test : MART), and velocity of middle distance running ( V $800 \mathrm{~m}, \mathrm{~V} 1500 \mathrm{~m}$ ). The subjects were well-trained male middledistance runners $(n=8)$.

MART consisted of a variable number of 20 seconds runs on a treadmill with a 100 seconds recovery period between runs. The runs were performed ona a $4^{\circ}$ incline. After 40 second recovery, earlobe blood samples were taken and blood lactate concentrations were analyzed. The first run was performed at $250 \mathrm{~m} / \mathrm{min}$. Velocity of the treadmill was increased by $25 \mathrm{~m} / \mathrm{min}$ for each consecutive run until volitional exhaustion.

The power requirement associated with the absolute value of blood lactate ( $\mathrm{La}$ ) and relative value of peak blood lactate (PBLa) was determined from the La or \%PBLa vs power curve by linear interpolation from the two consecutive $L$ a values which were above and below the desired value.

Results were summarized as follows :

(1) Maximal power $(\mathrm{Pmax})$ for MART was correlated positively with $\mathrm{V} 800 \mathrm{~m}(\mathrm{r}=0.880, \mathrm{P}<$ $0.01)$ and $\mathrm{V} 1500 \mathrm{~m}(\mathrm{r}=0.948, \mathrm{p}<0.001)$

(2) Power estimated at $40 \%$ value of PBLa (P40\%La) correlated positively with $\mathrm{V} 1500 \mathrm{~m}(\mathrm{r}=$ $0.903, \mathrm{P}<0.01)$, and at $60 \%$ value of PBLa $(\mathrm{P} 60 \% \mathrm{La})$ was correlated positively with $\mathrm{V} 800 \mathrm{~m}(\mathrm{r}=$ $0.835, \mathrm{P}<0.01)$ and $\mathrm{V} 1500 \mathrm{~m}(\mathrm{r}=0.936, \mathrm{p}<0.001)$.

These results indicate that MART is a valid test for estimating middle distance running per. formance and $\mathrm{P} 40 \% \mathrm{La}$, and $\mathrm{P} 60 \% \mathrm{La}$ are important indexes with $800-\mathrm{m}$ and $1500-\mathrm{m}$ running.

(Jpn. J. Phys. Fitness Sports Med. 2003, $52: 285 \sim 294$ )

key word : middle-distance running, maximal anaerobic running test, blood lactate, anaerobic power, aerobic power
\end{abstract}

\section{I. 緒 言}

陸上競技における $800 \mathrm{~m}$ 走および $1500 \mathrm{~m}$ 走 は, 『中距離走 (Middle-distance running)』に分
類される.この分類に基づいて,多くの研究では, $800 \mathrm{~m}$ 走者および $1500 \mathrm{~m}$ 走者を「中距離走者 (Middle-distance runner)」と一括し，主に他の 走種目との比較によって, その生理学的特性を明

\footnotetext{
${ }^{1)}$ (財)日本体育協会スポーツ科学研究坴

テ 150-8050 東京都渋谷区神南1-1-1 岸記念体育会館内

2) 大分工業高等専門学校

干870-0152 大分晾大分市大字牧1666番地

3) 順天堂大学:大学院

干270-1695 千枼県印旛郡印旛村平賀学溒台1-1

Sports Science Laboratory, Japan Amateur Sports Association 1-1-1 Jinnan, Shibuya-ku, Tokyo (150-8050)

Oita National College of Technology

1666 Oaza-maki. Oita-city, Oita (870-0152)

Juntendo Liniversity

1-1 Hiraga-gakuendai, Inba-village, Inba-gun, Chiba (270-1606)
} 
らかにしてきている。長距離 $(5000 \mathrm{~m}$ 以上) 走者 との比較においては, 運動後の最高血中乳酸值や MAOD (Maximal Accumulated Oxygen Deficit), EPOC (Excess Post-exercise Oxygen Consump. tion）など無気的能力に優れていること ${ }^{1-7) ， ま ~}$ た, 短距離 (400 m 以下) 走者との比較においては, 最大酸素摂取量 (VO2max), や走行中の血中乳酸 (La) 濃度が低いといった有気的能力に優れる ${ }^{8-~}$ 10)ことが示されており，これらは，中距離走者 の特性を示す貴重な報告であるといえるだろう。

しかし，一口に中距離走といっても，例えば一流 選手において 1 分40秒〜50秒でレースが終了する $800 \mathrm{~m}$ 走と, 抢よそその倍の運動時間 (3 分 30 秒 ～40秒)を要する $1500 \mathrm{~m}$ 走では, それぞれの種 目特性や選手の生理学的特性も異なるものと思わ れる.これは, $800 \mathrm{~m}$ のみ, $800 \mathrm{~m}$ と $1500 \mathrm{~m}, 1500$ $\mathrm{m}$ と $5000 \mathrm{~m}$ をそれぞれ専門種目とする…流選手 に扔ける最大酸素掑取量やLa動態に有意差がみ られること文や， $800 \mathrm{~m}$ 走中の有酸素エネルギー 供給系の貢献度が 60 ～70\%であるのに対して， $1500 \mathrm{~m}$ 走中では80\%を超えること ${ }^{11.12)}$ などから も明らかであろう。また，持久的トレーニングに おいては, 無気的能力, 有気的能力の両方を評価 し，その優少のバランスを知ることによって，適 切なトレーニング目標を設定することが重要であ

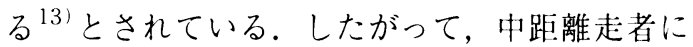
対して適切なトレーニングを処方するためには, 中距離走の競技特性をふまえると同時に，個々の 選手の特性を十分考虑した上でトレーニングを設 計していくことが重要であろう。そのためには, $800 \mathrm{~m}$ 走拉よび $1500 \mathrm{~m}$ 走の種目特性や個々の選 手の生理学的特性を反映する体力テストや，その 評価指標が必要になると思われる.

そこで本研究では，中距離走 $(800 \mathrm{~m}$ 抢よび $1500 \mathrm{~m}$ )を専閏とする被験者を用いて間久的な漸 增負荷走行を行い，走行中の $\mathrm{La}$ 動態から推定さ れるパワーと中距離走能力との関係について明ら かにし，中距離走能力を反映する新しい評価指標 を作成するための基礎的資料を得ることを目的と した。
II. 方法

\section{A．被験者}

被騒者は，大学陸上競技部に所属する男子で,

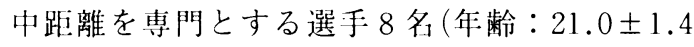
歳, 身長: $174.7 \pm 5.8 \mathrm{~cm}$, 体重: $63.7 \pm 4.4 \mathrm{~kg}$,

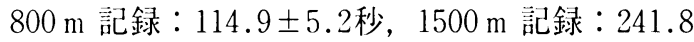
\pm 14.7 秒)であった。な扮，中距離走記録は，本 実験の奏施日から半年以内の公認記録を採用し た。

実験に先立ち，被験者には，プロトコールなど (実験後半はかなりの高速走行になること，転倒 回避のため走行中トレッドミル室上部に固定した ベルトを装着すること,ベルトに $5 \mathrm{~kg}$ 以上の負 荷がかかった場合はトレッドミルが自動停止する こと，なども含む)について詳しく説明し，本実 験への参加協力の同意を得た。

\section{B. Maximal Anaerobic Running Test (MART)} について

本研究では, パワーを推定するために Maximal Anaerobic Running Test(MART)を用いた。これ は，Anaerobic power を測定するテストとして広 く用いられているものであり，すでに先行研究に おいてその信頼性および妥当性が検証されてい $ろ^{14 \sim 17)}$.

Fig. 1 は, MARTのプロトコールを示したも のである、トレッドミル傾斜については，5度を 採用している先行研究 ${ }^{17.18)}$ もみられるが，5度 での走行の場合，短距離走者は exhaustion 時に 最大の anaerobic power に至らない可能性がある ことや ${ }^{18.19)}$ ，その後の研究の多くが4 度を採用 している 15.16 .20 22) ことなどから，本研究にお いては傾斜 4 度を採用することとした.被験者は， 傾斜のついた既に回転しているトレッドミルに安 全バーをつかみながら跳び乗り，1２秒間脚の 動きを合わせた後に手を放し，20秒間走行を行っ た。初回の走速度は, Exhaustionに至るまでに 8 10回程度の走行が可能で, しかも終了後の La が $3 \mathrm{mmol} / 1$ 以上にあがらない速度として 250 $\mathrm{m} / \mathrm{min}$ を採用した，走行終了から 100 秒後に，走 


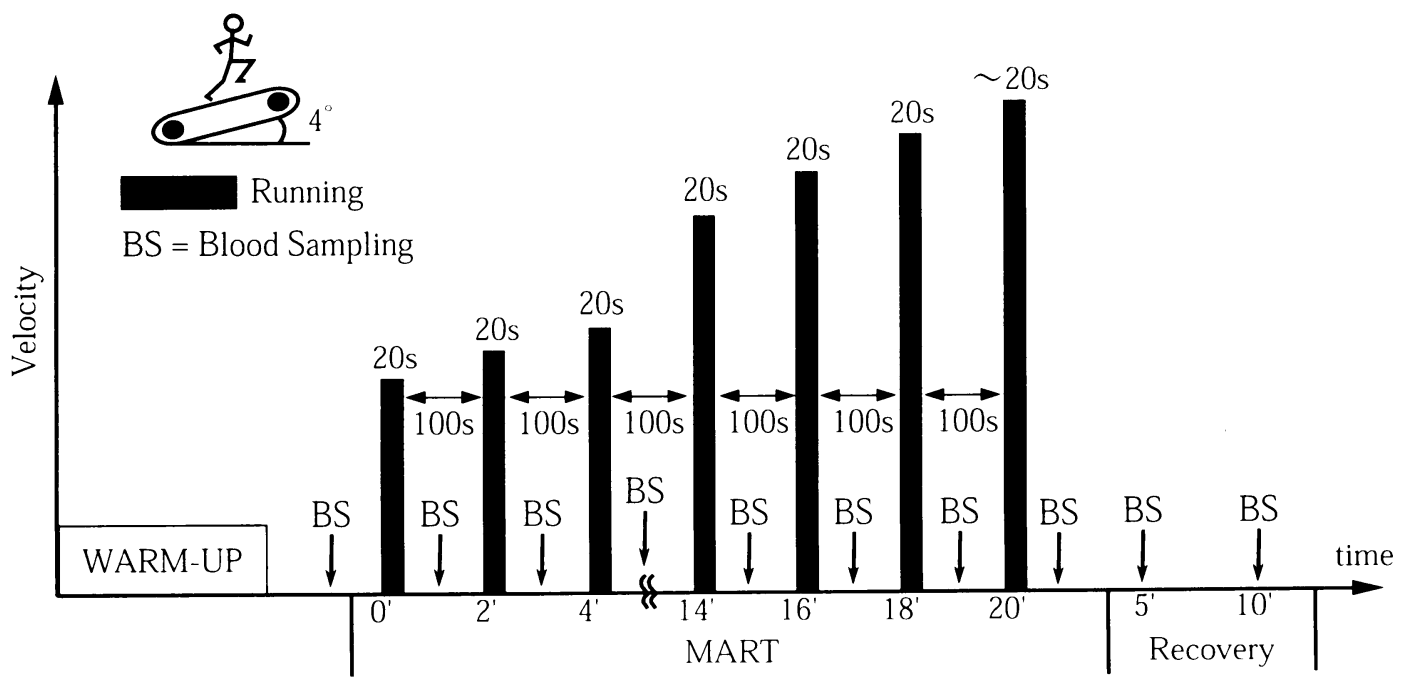

Fig. 1. Schematic presentation of the MART protocol.

速度を $25 \mathrm{~m} / \mathrm{min}$ 漸増させ $(275 \mathrm{~m} / \mathrm{min})$ 再び次の 走行をスタートした。以後, 同様のサイクルで 25 $\mathrm{m} / \mathrm{min}$ ずつ走速度を漸増し, 被騃考がExhaus. tionに至るまで 8 回 $(425 \mathrm{~m} / \mathrm{min}$ 走行) から10 以 $(475 \mathrm{~m} / \mathrm{min}$ 走行)の走行を繰り返した。各走行終 了後40秒の時点，および Exhaustionに至る走行 が終了して 1，5，10分後にそれぞれ耳梨採血孛 行い, 自動乳酸分析器 (BIOSEN-5040) を用いて La の分析を行った。

\section{C. 算出するパラメータについて}

本研究で用いるパワーの指標である酸素需要量 (ml/kg/min)は, American College of Sports Medicine (ACSM)のガイドライン 23) および Rusko et al. ${ }^{17)}$ の方法に基づき，以下の式にて算出した。

$$
\dot{\mathrm{VO}_{2}}=0.2 \mathrm{v}+0.9 \text { grade } \cdot \mathrm{v}+3.5
$$

$\dot{\mathrm{V}} \mathrm{O}_{2}=$ 酸素需要量 $(\mathrm{ml} / \mathrm{kg} / \mathrm{min}), \mathrm{v}=$ トレッドミル スピード $(\mathrm{m} / \mathrm{min})$, grade=トレッドミルの傾斜 (tangent, 傾斜 40場合は0.0699)，3.5=交静 時の酸素摂取量 $(\mathrm{ml} / \mathrm{kg} / \mathrm{min})$

実験時の走力を表す最大パワー(Pmax)につい ては, exhaustion に至ったセットに㧍ける 9 秒以 下の走行時間はキャンセルするというRuskoet al. (1993) および森斥たち(2003)の方法を参考に, 以下の式にて算出した。
$P \max (\mathrm{ml} / \mathrm{kg} / \mathrm{min})=$ 最後に20秒完走したセット の酸素需要量 $(\mathrm{ml} / \mathrm{kg} / \mathrm{min})+($ exhaustionしたセッ トの赴行時間- 9 (秒) $) \times 0.6(\mathrm{ml} / \mathrm{kg} / \mathrm{min})$

exhaustion したセットの走行時間が 9 秒以下の 場合は，最後に20秒完走したセットの酸素需要量 を用いる。例えば， 8 セット目 $(425 \mathrm{~m} / \mathrm{min}$ 走行 $)$ を完起 9 セット日 $(450 \mathrm{~m} / \mathrm{min}$ 走行)の 9 秒以内 で exhaustionに去った場合は $115.2 \mathrm{ml} / \mathrm{kg} / \mathrm{min}$ となり，9セット目の10秒で exhaustionに至っ た場合は $115.2 \mathrm{ml} / \mathrm{kg} / \mathrm{min}+(10-9) \times 0.6 \mathrm{ml} /$ $\mathrm{kg} / \mathrm{min}=115.8 \mathrm{ml} / \mathrm{kg} / \mathrm{min}$ という計算になる.

MART 終厅後のピークLa(PBLa)は, exhaus. tion の 1 分後, 5 分後, 10 分後の值の中で最も高 いものを採用した。また，Laの絶対值 $(3 \mathrm{mmol} / 1$, $5 \mathrm{mmol} / 1 ， 8 \mathrm{mmol} / \mathrm{l})$ を基準とした最大下パワー (P $3 \mathrm{mM}, \quad$ P $5 \mathrm{mM}, \quad$ P $8 \mathrm{mM})$ 抢よびPBLa の相対 佔（\%PBLa；PBLa の20\%, 40\%，60\%の La)を 基隻とした最大下パワー（P20\% La， P40\% La， $\mathrm{P} 60 \% \mathrm{La}$ )については、各被験者の $\mathrm{La}$ ーパワー曲 線抢よび\%PBLa一バワー曲線( La 動態における 連続する 2 点間を直線回帰により内挿したもの) により算出した(Fig. 2)。なお，パワ一算憬基準 の上限となる $8 \mathrm{mmol} / 1$ 拈よび $60 \%$ PBLaは，全 ての被験者において最大下パワーを算出すること ができる值として採用した。 

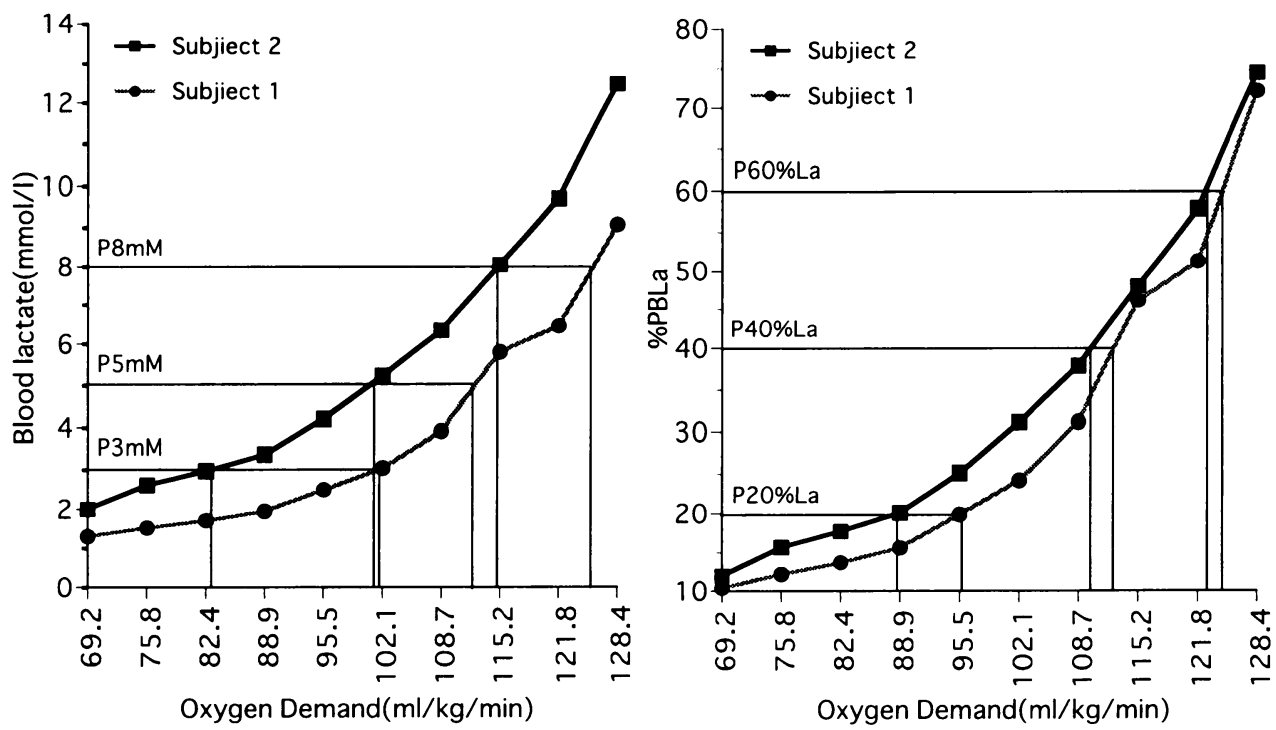

Fig. 2. Determination of $P 3,5,8 \mathrm{mM}$ and P $20,40,60 \% \mathrm{La}$.

\section{D. 統計処理}

相関分析には，ピアソンの積率相関分析を用い た。また，有意差検定には，一元配置分散分析 (ANOVA) とScheffe's post hoc testを用いた。そ れぞれの有意性の判定には，危険率 $5 \%$ 未満を採 用した。

\section{III. 結果}

Table 1 は, 8 名の被験者の中距離走能力およ
び本研究において算出した各パラメータを示した ものである. $800 \mathrm{~m}$ および $1500 \mathrm{~m}$ 走記録は, 800 $\mathrm{m}$ 走, $1500 \mathrm{~m}$ 走の平均走速度 (秒速： $\mathrm{V} 800 \mathrm{~m}$, V 1500 m)で示した.

Fig. 3 は, V 800 m, V $1500 \mathrm{~m}$ と Pmax および PBLa との関係について示したものである.V 800 $\mathrm{m}, \mathrm{V} 1500 \mathrm{~m}$ と $\mathrm{Pmax}$ との間には，ともに有意な 相関関係 $(\mathrm{r}=0.880, \mathrm{P}<0.01 ; \mathrm{r}=0.969, \mathrm{P}<$ 0.001)がみられたが, PBLa との間には認められ

Table 1. Physiological Characteristics and performances of subjects.

\begin{tabular}{ccccccccccc}
\hline $\begin{array}{c}\text { Subject } \\
\text { no. }\end{array}$ & $\begin{array}{c}\text { V } 800 \mathrm{~m} \\
(\mathrm{~m} / \mathrm{min})\end{array}$ & $\begin{array}{c}\mathrm{V} 1500 \mathrm{~m} \\
(\mathrm{~m} / \mathrm{min})\end{array}$ & $\begin{array}{c}\text { PBla } \\
(\mathrm{mmol} /)\end{array}$ & Pmax & P3mM & P5mM & $\begin{array}{c}\text { P8mM } \\
(\mathrm{m} / \mathrm{kg} / \mathrm{min})\end{array}$ & P20\%La & P40\%La & P60\%La \\
\hline 1 & 435.8 & 390.5 & 12.57 & 124.8 & 101.6 & 112.4 & 124.0 & 95.7 & 112.5 & 124.5 \\
2 & 435.2 & 394.0 & 16.76 & 124.2 & 82.9 & 100.7 & 115.0 & 88.6 & 110.1 & 122.7 \\
3 & 432.4 & 392.2 & 15.46 & 125.6 & 80.0 & 103.2 & 116.0 & 81.2 & 108.6 & 118.8 \\
4 & 427.8 & 366.0 & 14.38 & 122.4 & 89.8 & 104.7 & 115.8 & 88.0 & 108.0 & 117.9 \\
5 & 422.2 & 392.7 & 16.79 & 127.2 & 90.0 & 104.2 & 115.9 & 92.3 & 112.0 & 120.7 \\
6 & 403.4 & 365.9 & 14.45 & 117.6 & 91.1 & 105.4 & 115.0 & 90.2 & 109.0 & 116.5 \\
7 & 402.3 & 339.6 & 13.85 & 114.7 & 82.6 & 95.5 & 107.4 & 79.6 & 97.7 & 108.6 \\
8 & 387.1 & 346.3 & 13.72 & 115.3 & 85.9 & 100.9 & 111.5 & 83.9 & 103.2 & 112.0 \\
\hline mean & 418.3 & 373.4 & 14.75 & 121.5 & 88.0 & 103.4 & 115.1 & 87.4 & 107.6 & 117.7 \\
SD & 18.3 & 22.1 & 1.49 & 4.90 & 6.8 & 4.8 & 4.7 & 5.5 & 4.9 & 5.3 \\
\hline
\end{tabular}



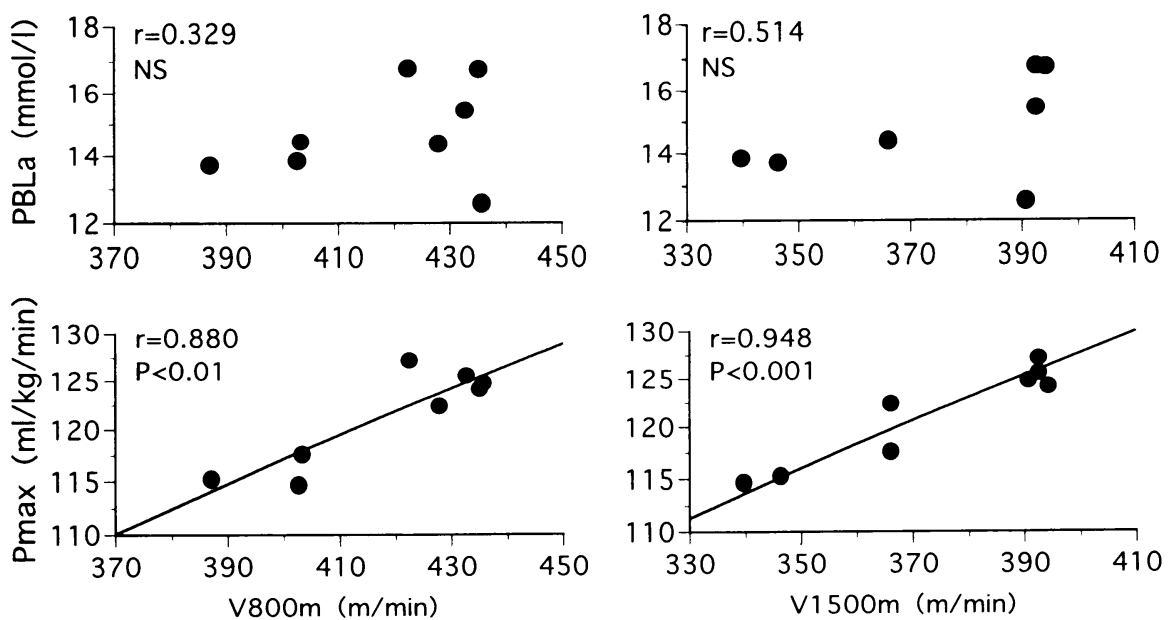

Fig. 3. Relationship between V $800 \mathrm{~m}, \mathrm{~V} 1500 \mathrm{~m}$ and Pmax, PBLa.

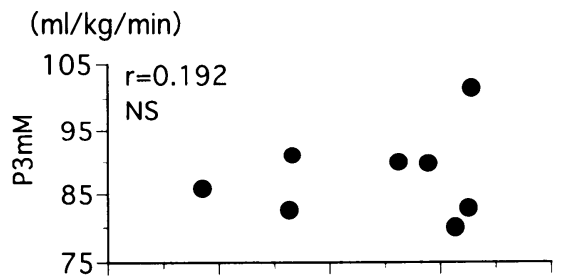

$(\mathrm{ml} / \mathrm{kg} / \mathrm{min})$
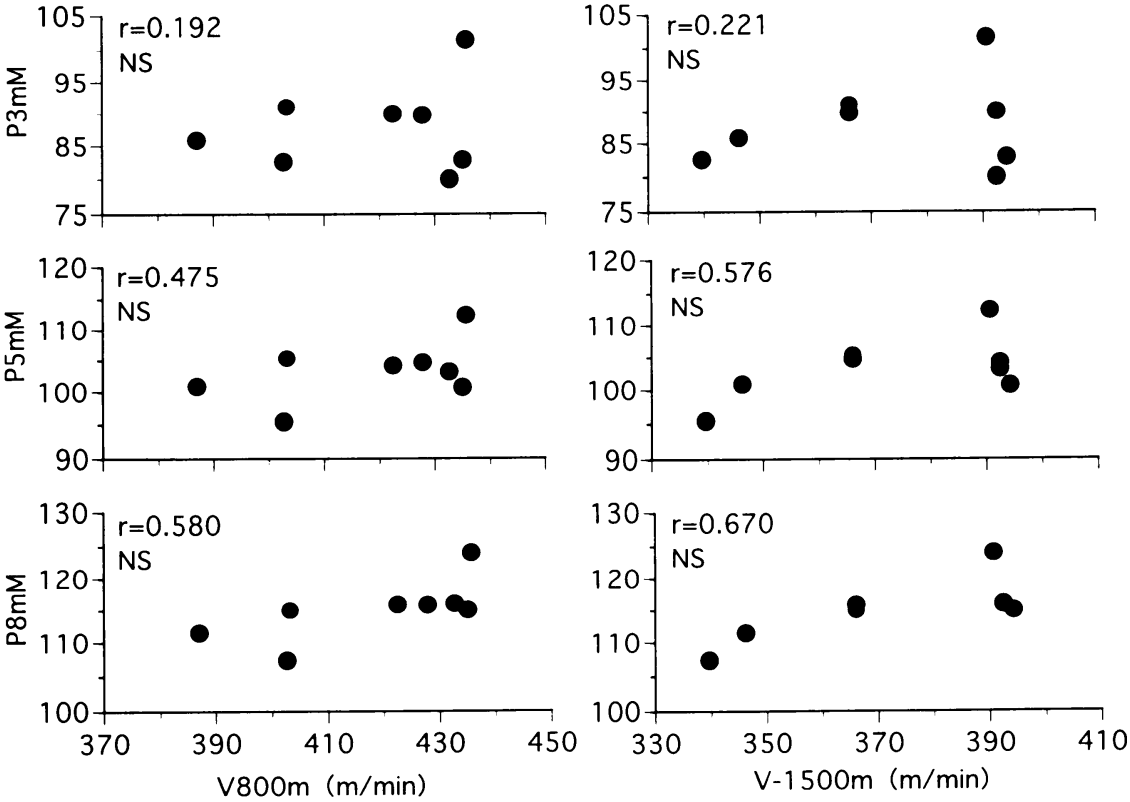

Fig. 4. Relationship between V $800 \mathrm{~m}, \mathrm{~V} 1500 \mathrm{~m}$ and P 3, 5. $8 \mathrm{mM}$

なかった。

Fig. 4 は, V $800 \mathrm{~m}, \mathrm{~V} 1500 \mathrm{~m}$ と P $3 \mathrm{mM}, \mathrm{P} 5 \mathrm{mM}$, $\mathrm{P} 8 \mathrm{mM}$ との関係について示したものである。い ずれの間にも有意な相関関係が認められた。

Fig. 5 は, V 800 m, V $1500 \mathrm{~m}$ と P20\%La, P40\% $\mathrm{La}, \mathrm{P} 60 \% \mathrm{La}$ との関係について示したものであ る. $\mathrm{V} 800 \mathrm{~m}$ と $\mathrm{P} 60 \% \mathrm{La}(\mathrm{r}=0.880, \mathrm{P}<0.01)$,
およびV $1500 \mathrm{~m}$ と $\mathrm{P} 40 \% \mathrm{La}(\mathrm{r}=0.903, \mathrm{P}<0.01)$ ， $\mathrm{P} 60 \% \mathrm{La}(\mathrm{r}=0.933, \mathrm{P}<0.01)$ との間に有意な相 関関係が認められた。 

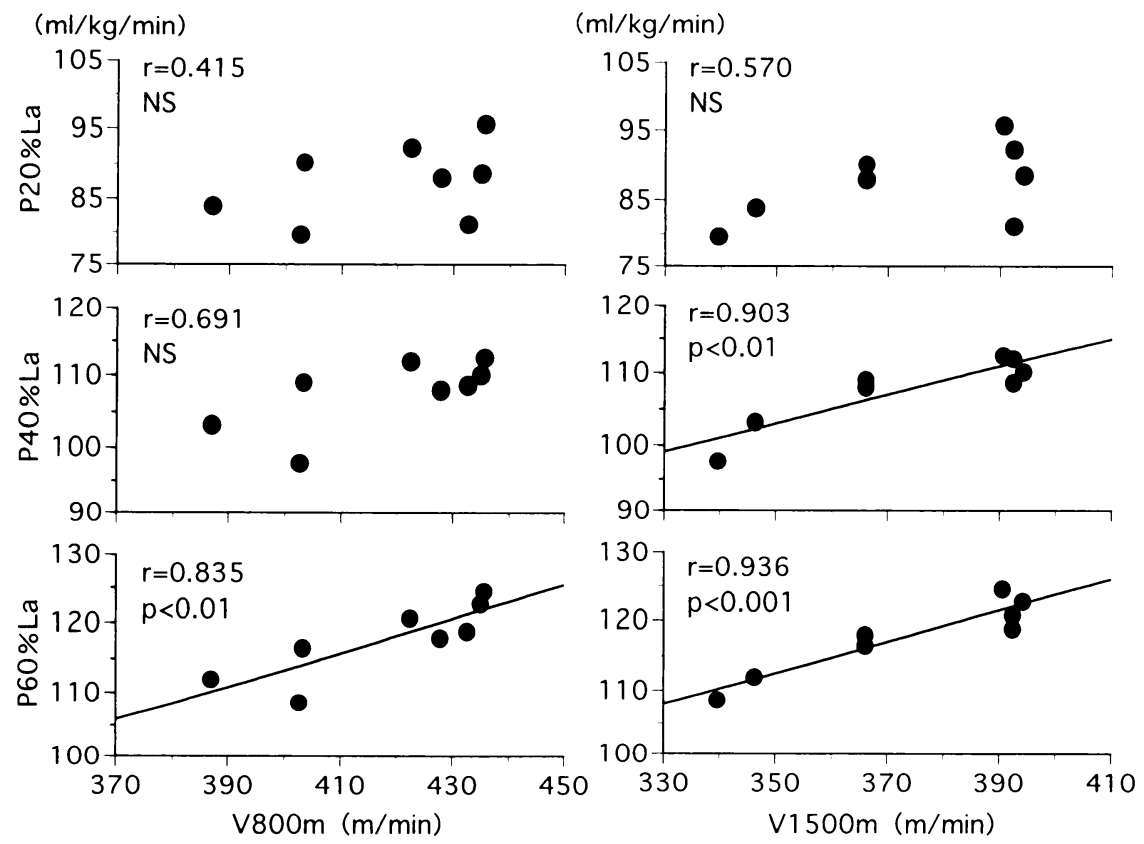

Fig. 5. Relationship between V $800 \mathrm{~m}, \mathrm{~V} 1500 \mathrm{~m}$ and P 20, 40, 60\% La.

\section{N. 考察}

\section{A. La の絶対値をもとに算出されたパワーに ついて}

$\mathrm{V} 800 \mathrm{~m}, \mathrm{~V} 1500 \mathrm{~m}$ と $\mathrm{Pmax}$ との間に有意な相 関関係が認められたことから，MART が中距離 走能力を反映するテストであることが示された (Fig. 3).

Fig. 6 は, V $800 \mathrm{~m}, \mathrm{~V} 1500 \mathrm{~m}$ およびPmax が ほぼ同レベルの走者 2 名(Table 1 を参照)におけ るMART 中および終了後の La 動態を比較した ものである. subject 1 は，全ての被験者のなか で最大下負荷時の La および PBLa において最も 低い值 $(12.57 \mathrm{mmol} / \mathrm{l})$ を示し, subject 2 は, 最大 下負荷時の La および PBLa $(16.76 \mathrm{mmol} / \mathrm{l})$ まで 高い值を推移していた，速筋線維(FT) では解糖 系酵素活性が高く La 産生に傾くが，遅筋線維 （ST）では酸化能力が高く La の産生が抑えられ

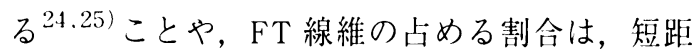
離走者が最も高く，以下中距離走者，長距離走者 の順に高いこと年,27)などはよく知られている. subject 2 は, 被験者のなかで最も䯩い $400 \mathrm{~m}$ 走
能力を有しており， subject 1 を含む他の被験者 に比べて \%FT や解糖系酵素活性が高い，すなわ ちより短距離走者に近い生理学的特性であると推 察され，このことが，Fig. 6 にみられるようなLa 動態の相違を示す要因であると思われる。無酸素 性作業閾值 (AT)やWingate テストなどで測定さ 机る無気的パワーと中距離走能力との関係ついて 様々な報告がなされているが17,28－30), 統一し た見解は示されておらず，これらの結果の不一致 は，短距離走や長距離走を対象とした同様の研究

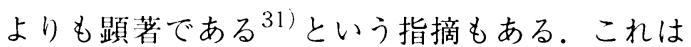
すなわち, 中距離走者における生理学的特性の多 様性を示すものであるといえるだろう。

Lacour et al. ${ }^{29)}$ は，一流中距離選手を対象に $800 \mathrm{~m}$ レース終了後の La を測定し，レース走速 度との間に有意な正の相関関係が認められたこと を報告している。しかしながら，本研究において は, PBLa とV $800 \mathrm{~m}$, V $1500 \mathrm{~m}$ との間に有意な 相関関係は認められなかった(Fig. 3)。また，La の絶対值を基準として算出したパワー（P $3 \mathrm{mM}$, P $5 \mathrm{mM}$, P $8 \mathrm{mM})$ と V $800 \mathrm{~m}, \mathrm{~V} 1500 \mathrm{~m}$ との間に も有意な相関が認められなかった(Fig. 4)。森丘 


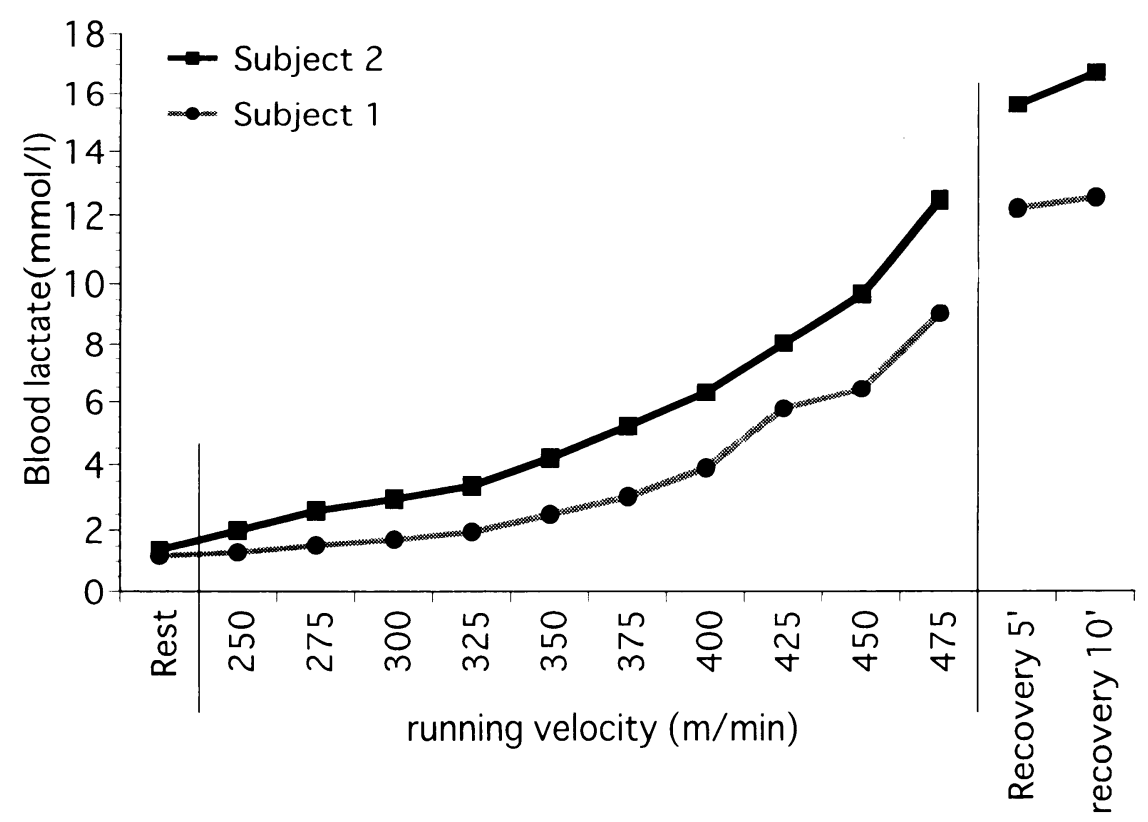

Fig. 6. Blood lactate curve of Subject 1 and Subject 2 .

たち ${ }^{15)}$ は，同等の $400 \mathrm{~m}$ 走能力を有する知距離， 中距離および十種競技選手によるMARTを行 い，Laの絶対值を基準に算出したパワーと400 $\mathrm{m}$ 走記録との間に有意な関倸がみら札なかった ことから，同種目で同等の走力を有する走者間で も，その生理学的特性は多様であるため，その評 価において各走者の生理学的特性を十分考慮する 必要があると指摘している。本研究では中距離走 者のみを対象としているが，こ狄らの結果は，先 に示した La 動態の相違(Fig. 6)なども考虑すれ ば，十分に予想される結果であったといえる。 Yoshida et al. ${ }^{32 \prime}$ は, $800 \mathrm{~m}$ から $3000 \mathrm{~m}$ 走者の比 較に扔いて， $800 \mathrm{~m}$ 走者のみ们気的パワー拈よび 無気的パワーの両力に有意な相関関倸が浔められ たことから， $800 \mathrm{~m}$ 走で高いパフォーマンスを澾 成するためには，それぞれのエネルギー供給系の 貢献度のバランスが鍵であるとしている。また， 中距離走者に比べて，より無気的能力に依存する とされる短距離走者の有気的能力や，上り你独的 能力に依存するであろう長距離走者の無:父的能ノ の重要性なども指摘されている18.32-31!。これ らのことは, 中距離走者においては, 個々の走者 の生理学的特性を把握することが重要であると同
時に，有気的および無気的能力のバランスなどを 考虑した評価指標が必要であることを示唆してい るといえよう。

\section{B. \%PBLa を基準に算出されたパワーについ} $\tau$

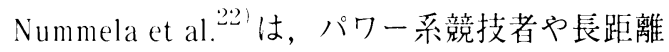
走者に比べて, 知距離走者や中距離走者の P 10 $\mathrm{mM}$ が有意に高かったことから，この指標が，400 $\mathrm{m}$ から $1500 \mathrm{~m}$ までの越バフーマンスの重要な 決㳬要因になりうるとしている。しかしながら， 被験者の生理学的特性によって Laの動態に差が みられるため, P $3 \mathrm{mM}$ や P $10 \mathrm{mM}$ が推定できな い場合があることや15.21〉，連動ゆの La 動態は 個人差が大きいため, AT の幅が $1.4 \sim 7.5$

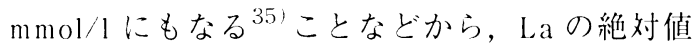
を評価基準として用いることの難しさも示唆され ている ${ }^{\top}$. 本研究に扔いても, exhaustion 直後の Laが $10 \mathrm{mmol} / 1$ を超えなかった被験者が数多いた ために，P $10 \mathrm{mM}$ を算出し，中距離走能力との関 係について検詂することができなかった。これら のことを踏まえ，森斦たち ${ }^{15)}$ は，La の再利用， 除去といった L a 举生の抑制に貢献する有気的能 
力と, $\mathrm{La}$ の産生に貢献する無気的能力とを勘案 した評価指標として\%PBLa を基準としたパワー を算出し，P60\%La と $400 \mathrm{~m}$ 走記録との間に有意 な相関関係が認められたことを報告している。本 研究においても, 同様の方法を用いて中距離走能 力との関係について検討した結果， $\mathrm{P} 60 \% \mathrm{La}$ と $\mathrm{V} 800 \mathrm{~m}, \mathrm{P} 40 \% \mathrm{La}, \mathrm{P} 60 \% \mathrm{La}$ と V $1500 \mathrm{~m}$ との間 に有意な相関関係が認められた (Fig. 5)。10 $\mathrm{mmol} / \mathrm{l}$ 程度の $\mathrm{La}$ におけるパワーはスプリント エコノミーの評価指標である ${ }^{15,17,22)}$ とされてい るが, 本研究の被験者の $60 \% \mathrm{PBLa}$ は $8.85 \pm 0.89$ $\mathrm{mmol} / \mathrm{l}$ であったことから, 中距離走においては, La が $8 \sim 10 \mathrm{mmol} / \mathrm{l}$ 時の発揮パワーが，パフォー マンスに影響を与える重要な要因であることを示 したといえるだろう。

$800 \mathrm{~m}$ 走中の有酸素エネルギー供給系の貢献度 が60〜70\%であるのに対して，1500 m 走中では 80\%を超えるといわれている ${ }^{11,12)}$ 。また， Lacour et al. ${ }^{2)}$ は, OBLA (Onset Blood Lactate Accumulation) と $800 \mathrm{~m}$ から $5000 \mathrm{~m}$ までのレー ス走速度との関係について調べ, $1500 \mathrm{~m}$ 以上の 距離の走速度と相関があったことを示している。 これらのことは， $1500 \mathrm{~m}$ が $800 \mathrm{~m}$ に比べてより 有気的能力への依存度が高いことを示すものであ る。本研究において, P 40\% La が V $1500 \mathrm{~m}$ との 間にのみ有意な相関関係を示したことは，MART における最大下のパワーと $\dot{\mathrm{VO}}_{2} \max$ や AT とい つた有気的能力に関する指標との関係が深い ${ }^{18)}$ ことなどを考えても， $800 \mathrm{~m}$ に比べてより最大下

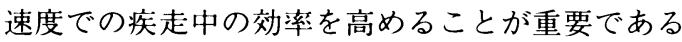
ことを示唆しているといえよう。さらに言えば, $\mathrm{V} 1500 \mathrm{~m}$ と P $5 \mathrm{mM}$ ，P $8 \mathrm{mM}$ との間に相関がみ られなかったにもかかわらず，P40\%La (40\%PBLa は $5.9 \pm 0.6 \mathrm{mmol} / \mathrm{l})$ との間に有意な相関関係が 認められたことは，P 40\%La が，La の絶対值を 基準に算出された従来の指標に比べて，ょり $1500 \mathrm{~m}$ 走能力を反映した実用的な指標であるこ とを示したともいえる。

$\mathrm{La}$ は，産生と除去(再利用)のバランスや，筋 中から血中に拡散するまでの時間などによって決 定されるので, 運動後の $\mathrm{La}$ 濃度から運動中の乳
酸産成量を直接評価できないこと,そして被験者 の筋線維組成や代謝特性だけでなく，トレーニン

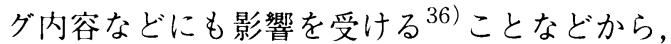
個人間での比較は難しいとされている。しかしな がら，本研究の結果は，\%PBLa を基準に算出さ れたパワー(P 40\% La，P 60\%La) が，中距離走能 力を反映する指標の一つとして用いることのでき る可能性を示したといえよう。

\section{V. 要 約}

本研究の目的は，中距離走者を対象に間欠的な 漸増負荷走行テスト (MART) を行い，La 動態か ら推定されるパワーと中距離走能力との関係を検 討することであった。

結果の要約を以下に示す。

(1) V $800 \mathrm{~m}, V 1500 \mathrm{~m}$ と実験時の走力を表す最大 パワー $(\mathrm{P} \max )$ との間に有意な相関関係が認め られた。

(2) V $800 \mathrm{~m}$ とピーク $\mathrm{La}(\mathrm{PBLa}) の 60 \%$ 值 (60\%PBLa) を基準に算出したパワー(P 60\% La)，V $1500 \mathrm{~m}$ と PBLa の40\%值 (40\%PBLa)を基準に算出した パワー(P 40\%La) および P 60\%La との間に有意 な相関関係が認められた。

以上のことから，MART が中距離走能力を反 映するテストとして有用であること，また， $\mathrm{P}$ $60 \% \mathrm{La}$ が $800 \mathrm{~m}$ 走能力, $\mathrm{P} 40 \% \mathrm{La}$ および $\mathrm{P}$ $60 \% \mathrm{La}$ が $1500 \mathrm{~m}$ 走能力を反映する評価指標の一 つとして利用可能であることなどが示された。

(受理日 平成15年 3 月28日)

\section{V. 文}

1）黑田善雄，伊藤静犬，塚越克己，雨宮輝也，鈴木 洋児. 日本人一流競技選手の最大酸素摄取量並び に最大酸素負債量一第 2 報一，昭和48年度日本体 育協会スポーツ科学研究報告，(1973），1-27

2) Lacour, J. R., Padilla-Magunacelaya, S., Barthelemy, J. C. and Dormois, D. The energetics of middledistance running. Eur. J Appl. Physiol., (1990), 60. $38-43$.

3) Mckenzie, D. C., Parhouse, W. A. and Hearst, W. E. Anaerobic performance characteristics of elite cana. dian 800 meter runners. Can. J. Appl. Sports Sci. (1982), 7, 158-160.

4）佐伯徹郎，鍋倉賢治，高松 蕉. 漸增偩荷走行テ 
ストにおける生理学的応答からみた中距離走者と 長距離走者の相違, 体力科学, (1999)，48，385392.

5) Scott, C. B., Roby, F. B., Lohman, T. G. and Bunt, J. C. The maximally accumulated oxygen deficit as in dicator of anaerobic capacity. Med. Sci. Sports Ex. erc., (1991), 23, 618-624.

6) Schnabel, A. and Kindermann, W. Assessment of anaerobic capacity in runners. Eur. J. Appl. Physiol.. (1983), 52, 42-46.

7) Svedenhag. J. and Sjodin, B. Maximal and submax. imal oxygen uptake and blood lactate levels in elite male middle- and long-distance runners. Int. J. Sports Med..(1984), 5, 255-261.

8) Gramier, P., Mercier, B., Mercier, J. and Prefaut, C. Aerobic and abaerbic contribution to wingate test performance in sprint and middle-distance runners. Eur. J. Appl. Physiol..(1995), 70, 58-65.

9) Ohkuwa, T., Kato, Y., Katsumata, K., Nakao, T. and Miyamura, M. Blood lactate and glycerol after 400-m and 3000-m runs in sprint and long distance runners. Eur. J. Appl. Physiol., (1984), 53, 213-218.

10) Olesen, H. L., Raabo, E., Bangsbo, J. and Secher, N. H. Maximal oxygen deficit of sprint and middle dis. tance runners. Eur. J. Appl. Physiol.. (1994), 69. 140-146.

11) Spencer, M. R. and Gastin, P B. Energy system contribution during 200- to 1500-m running in highly trained athletes.. Med. Sci. Sports Exerc., (2001), 33. 157-162.

12) Craig. I. S. and Morgan. D. W. Relationship between 800-m running performance and accumulated oxygen deficit in middle-distance runners. Med. Sci. Sports Exerc., (1998), 30, 1631-1636.

13）永井 純, 山地佳寿美, 佐伯徹郎, 高松 薰. 800 $\mathrm{m}$ 走における短距離型および長距離型走者の体力 特性；同一記録を有する日本の一流女子走者の場 合. 陸上競技研究，(1993)，14，2-8.

14) Maxwell, N. S. and Nimmo, M. A. Anaerobic capacity : A maximal anaerobic running test versus the Maximal accumulated oxygen deficit. Can . J. Appl. Physiol., (1996), 21, 35-47.

15）森丘保典, 伊藤静夫, 持田尚, 大庭恵一, 原孝子, 内丸作，雨宮輝也. 間久的な漸増負荷走行中の血 中乳酸動態から推定されるパワーと $400 \mathrm{~m}$ 走記録 との関係。体育学研究, (2003), 48, 181-190.

16) Nummela. A., Mero. A. and Rusko, H. Effects of sprint training on anaerobic performance character. istics determined by the MART. Int. J. Sports Med., (1996), 17(Suppl. 2), 114-119.

17) Rusko, H., Nummela, A and Mero, A. A new method for the evaluation of anaerobic running power in athletes. Eur. J. Appl. Physiol., (1993), 66, 97-101.

18) Paavolainen, L.. Hakkinen, K.. Nummela, A. and Rus ko, H. Neuromuscular characteristics and fatigue in endurance and sprint athletes during a new anaero- bic power test. Eur. J Appl. Physiol.. (1994), 69. 199-126.

19) Nummela, A., Anderson, N., Hakkinen, K. and Rusko, H. Effect of inclination on the result of the maximal anaerobic running test. Int. J. Sports Med., (1996), 17(Suppl. 2) : 103-108.

20) Nummela, A. and Rusko, H. Time course of anaerobic and aerobic energy expenditure during short-term exhaustive running in athletes. Int. J. Sports Med. , (1995). 16 : 522-527.

21) Nummela, A., Mero, A., Stray-Gundersen. J. and Rusko, H. Important determinants of anaerobic run. ning performance in male athletes and non-athletes. Int. J. Sports Med., (1996), 17(Suppl. 2), 91-96.

22) Vuorimaa, T., Hakkinen, K., Vahasoyrinki, P. and Rusko. H. Comparison of three maximal anaerobic running test protocols in marathon runners, middledistance runners and sprinters. Int. J. Sports Med., (1996), 17, 109-113.

23) American College of Sports Medicine. ACSM's Guidelines for exercise testing and prescription. 5th ed., Williams \& Wilkins, Philadelphia, (1995), 277279.

24) Baldwin, K. M., Klinkerfuss, G. H., Terjing, P. A., Mole, P. A. and Holloszy. J. O. Respiratory capacity of white, red, and intermediate muscle: adaptative responce to exercise. Am. J. Physiol., (1972), 222. 373-378.

25) Madureira, G. and Hasson-Voloch, A. Lactate utilization and influx in resting and working rat red muscle. Comp. Biochem. physiology., (1988), 89A. 693-698.

26) Costill, D. L., Daniels, J., Evans, W., Fink, W.. Krahenbuhl, G. and Saltin, B. (1976): Skeletal muscle enzymes and fiber composition in male and female track athletes. J. Appl. Physiol., 40, 149-154

27）勝田茂, 宮田浩文, 麻場一徳, 土肥徳秀。二ー ドルバイオプシー法による各種スポーツ選手の筋 線維組成㧍よび毛細血管分布について. 筑波大学 体育科学系紀要，(1986)，9，175-180.

28) Brandon, L. J. and Boileau, R. A. Influence of metabolic, mechanical and physique variables on middle distance running. J. Sports Med. Phys. Fitness, (1992), 32, 1-9.

29) Lacour, J. R., Bouvat, E. and Barthelemy, J. C. Postcompetition blood lactate concentrations as indicators of anaerobic energy expenditure during 400-m and 800-m races. Eur. J. Appl. Physiol., (1990), 61, $172-176$.

30) Zacharogiannis, E. and Farrally, M. Ventilatory threshold, heart rate deflection point and middle distance running performance. J. Sports Med. Phys. Fitness, (1993), 33, 337-347.

31) Brandon. L. J. Physiological factors associated with middle distance running performance. Sports Med., (1995). 19, 268-277. 
32) Yoshida, T.,Udo, M., Iwai, K., Chida, M., Ichioka, M., Nakadomo, F. and Yamaguchi, T..Significance of the contribution of aerobic and anaerobic components to several distance running performances in female athletes.. Eur. J Appl. Physiol., (1990), 60, 249-25.

33）尾縣 貢 - 福島洋樹 · 大山圭悟 - 安井年文 - 関岡 康雄. 筋疲労時の疾走能力と体力的要因との関係. 体力科学, (1998), 47, 535-542.

34) Houmard, J. A., Costill, D. L., Mitchell, J. B., Park, S.
H. and Chenier, T. C.. The role of anaerobic ability in middle distance running performance. Eur. J Appl. Physiol., (1991), 62, 40-43.

35) Stegmann, H., Kindermann, W. and Schnabel, A. Lactate kinetics and individual anaerobic threshold. Int. J. Sports Med., (1981), 2, 160-165.

36）八田秀雄. 連動中および運動後における乳酸の代 謝とそのトレーニング効果. 体育の科学, (1991), 41, 305-310. 